\title{
ELECTRIC DRIVING IN THE PAPER MILL, ON HEAT-ECONOMY LINES.
}

\author{
By A. B. Mallinson, Associate Member.
}

(Paper first received 10 January, and in final form 7 February, 1921 ; read before the NORTH-WESTERN CENTRE 8 March, and before the Liverpool SuB-CENTRE 21 March, 1921.)

SUMMARY.

The various uses for which steam is required in paper manufacture are first discussed.

Then follow particulars of the various classes of machinery to be driven, and comments on the selection of suitable electrical gear. The heating requirements for heat economy. and the various types of power plant by which this can be attained are discussed in detail, together with recommendations on how each type of plant will be used for the different types of paper mills.

The utilization of existing prime movers on "heateconomy " lines is specially shown.

The factors governing the choice of electric supply are then dealt with

Finally, the driving of the variable-speed end of the paper machine proper is discussed in detail. The requirements for a successful drive are first enumerated, then various means of attaining that drive, not only with a single motor, but alternatively with several motors, both electrically and mechanically interlocked, are investigated.

A Table at the conclusion of the paper gives particulars of machines which have been converted for electrical working in the United Kingdom, and the total number of machines in the country.

\section{INTRODUCTION.}

As compared with most other manufacturing processes, the electrification of paper mills has, until the last year or so, been very backward. The paper maker is decidedly conservative, and this, coupled douttless with the unpleasant results of a few experimental installations, has made him very loath to abandon the present steam-driven machine lay-out, which has done its work so reliably.

There were undoubted signs, however, even in 1914, that paper makers were beginning to realize that, whilst their system of individual steam drive might be ideal as regards reliability, there were great possibilities of fuel economy to be attained by electrification of the paper machines in conjunction with a suitable heat-extraction power plant.

The post-war conditions of fuel supply have made the matter one of first importance, not only to the paper maker, but to the country in general. This, together with the possibilities for development in this country, are, the author considers, sufficient reasons for presenting a paper on the subject to this Institution.

The general requirements of paper-mill practice, and the possibilities of improvement in the economic utilization of heat and power, were dealt with from the paper makers' point of view very fully in a paper by Mr. W. Adamson, recently read before the Technical
Section of the Paper Makers' Association of Great Britain and Ireland, in Manchester.

The author hopes to carry the matter a stage further, by the discussion of the various types of possible prime mover, and particularly the electrical requirements for driving the paper machine.

\section{Manufacturing Reguirements}

For paper manufacture in this country steam is an absolute necessity, being used :-

(1) As a means of heating in the chemical treatment of the raw material, such as :-

(a) Waste paper boiling and softening at 1 to $15 \mathrm{lb}$ gauge pressure.

(b) Chemical pulp softening at 1 to $10 \mathrm{lb}$. gauge pressure.

(c) Rag boiling at 20 to $50 \mathrm{lb}$. gauge pressure.

(d) Esparto digestion at 30 to $60 \mathrm{lb}$. gauge pressure.

(e) Straw digestion at 40 to $70 \mathrm{lb}$. gauge pressure.

$(f)$.Soda recovery in esparto plants at 5 to $20 \mathrm{lb}$. gauge pressure.

(2) For the generation of power, to drive the beating, breaking, and refining plant, also the electric power and lighting plant. This is generally done by one of the orthodox types of compound condensing mill engines.

(3) For both power to drive and heat the drying cylinders of the paper machines, such heating steam being utilized at pressures of from 1 to $20 \mathrm{lb}$. (or even $30 \mathrm{lb}$.) per square inch.

(4) To warm the air in the buildings, particularly in the machine houses, and so obviate troubles from condensation, being used at 5 to $50 \mathrm{lb}$. pressure, depending on the type of heater.

(5) As a clirect or indirect heating medium for sundry purposes in the mill, such as accelerating bleaching, size mixing, softening of pulp, freeing of paper stock as delivered to machine, etc.

(6) Steam injectors for hosing down at machine wet end.

(7) Condensation losses in the distribution of the steam throughout the mill.

(8) In the boiler-house, for the auxiliaries in steam raising.

The steam requirements under the various headings vary materially for different classes of paper. Table 1 may be taken as representing very good practice in most mills ; for old mills which have not been brought up to date, the figures would be appreciably more. 
The variations are dependent on the quality of paper being made, process used, and class of raw materials used for furnish. tion. The general practice nowadays is to drive each paper machine by two independent high-speed engines; one, the "wet end" engine drives the agitators, screen,

TABLE 1

Pounds of Steari per Ton of Paper.

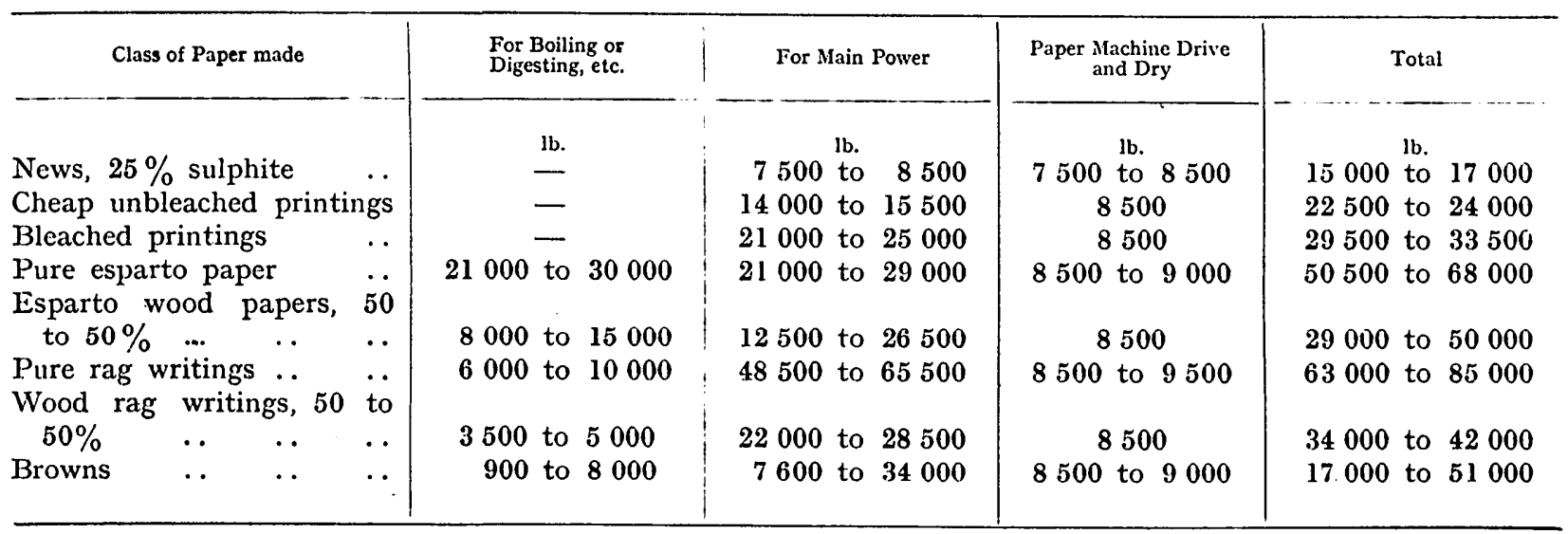

This Table shows some interesting points:-

(a) That it is obvious that no electrification scheme. from a public supply could entirely supersede the steam-raising plant, unless the power company happened to be so placed geographically that it could, in addition shake, and various pumps at a constant speed, and takes practically the same power for any speed of running of paper machine; the other, the "dry end" engine, is a variable-speed unit, the speed being varied according to the calliper of sheet to be made. These steam.

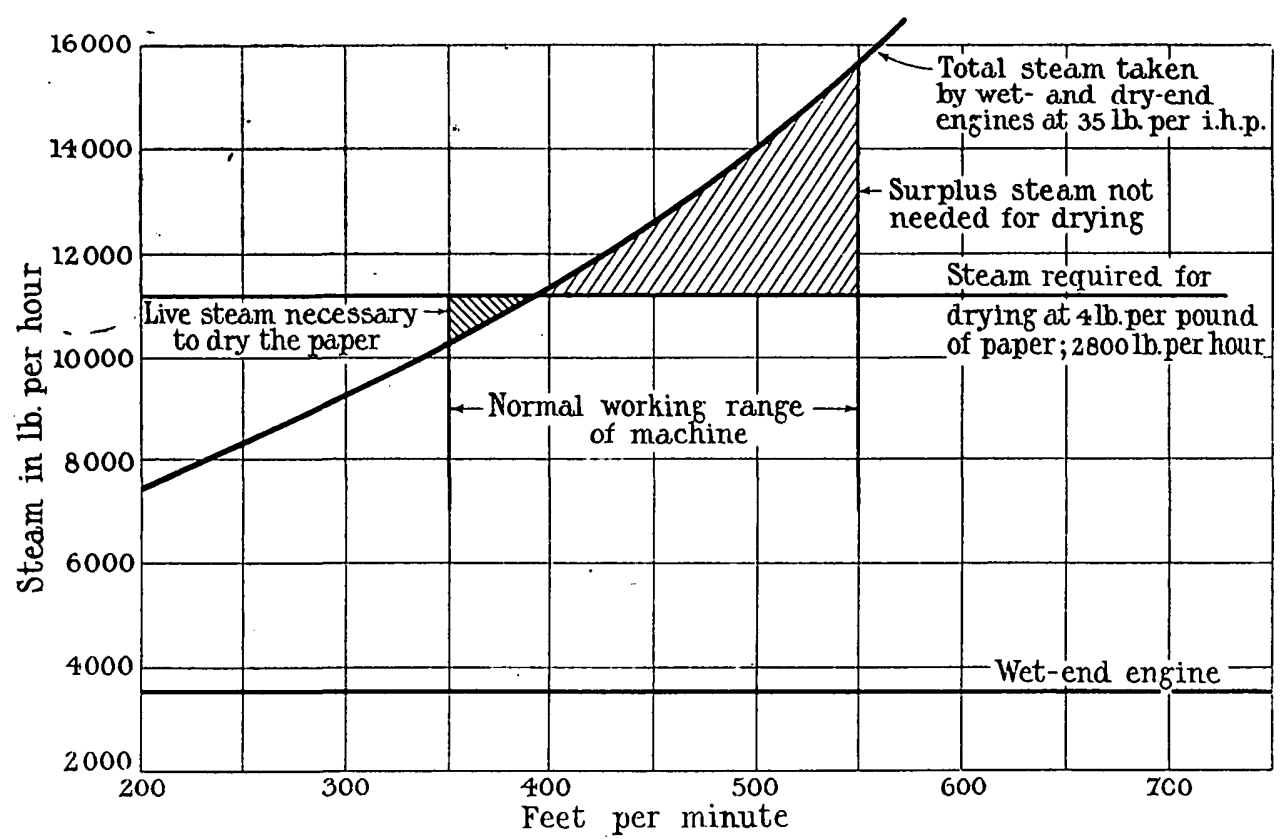

Frs. 1.-130-inch news machtne, approximate steam consumption for heating and power.

to supplying power, supply steam for heating and manufacturing purposes.

(b) That in every class of mill a practically constant quantity of steam per ton of paper is required for the paper-making machines. While on paper this is generally true, it is a factor liable to considerable varia- engines are almost invariably high-pressure engines consuming about $35 \mathrm{lb}$. per hour per indicated horsepower supplied from boilers at about 100 to $120 \mathrm{lb}$. pressure, or, if from a high-pressure boiler, through a reducing valve.

The weight of paper turned out per hour is approxi- 
mately constant, the speed being varied to suit the thickness of the sheet.

Fig. 1 shows how at one point only can the steam used for power correspond to the amount required for drying. If this point comes low down on the curve then there must be considerable surplus steam blown to waste when running at higher speeds.

(c) That in every class of mill (assuming, of course, there is little or no water power to augment the driving of preparation plant) enough heat passes away in the condensing water to supply all, or a considerable portion of, the requirements for heating purposes. required merit the closest investigation in any existing mill.

Driving Reyuirements on Heat-economy Lines.

These can be split up into:-

(1) Preparation.-Comprising rag and grass dusters, choppers, conveyors, rotary digesters, pulpers, bleach plant, etc., the details of which drives present no difficulties. Table 2 gives typical examples of such drives and the power taken under stated conditions of tests.

(2) Breaking, beating and refining.-Where the stock is treated until ready for letting down into machine

TABLE 2.

Preparation Plant Electric Drives.

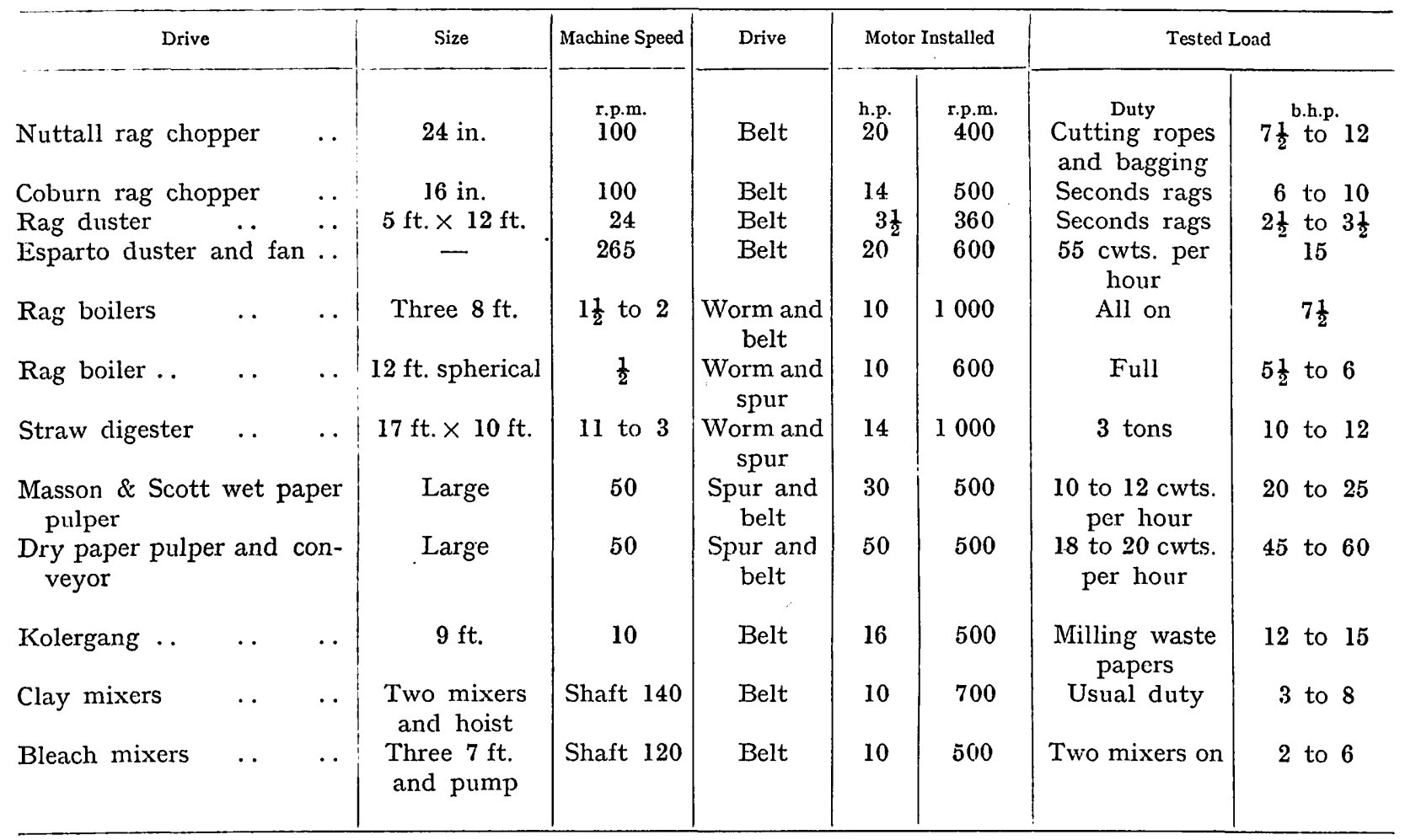

(d) That by the adoption of a suitable type of power unit, therefore, with such a steady demand for power and heating steam, the electrification of the paper machines, used for drying the steam from the power unit, is bound to lead to very material fuel economy.

\section{Financial Consideration.}

The whole object of any re-modelling on heat-economy lines is, of course, fuel saving; but capital outlay is, to the mill owner, with finance in its present state, of equal and probably, in many cases, greater importance.

Any scheme to justify. consideration not only must show marked fuel saving, but be a paying proposition after providing interest and depreciation, etc., on the whole capital outlay incurred at present-day rates.

In this respect the possibilities of utilizing the existing prime movers on heat-economy lines with the capital outlay restricted to the provision of the extra power chests. This section, comprising the bulk of the drive in any mill, is in present-day practice almost universally a mechanical grouped drive, the prime mover being coupled direct or by ropes to a main shaft in the beater cellar from which the various drives in turn are taken. Advantages of this system are:

(a) All machines require to run continuously to facilitate charging and discharging, so there is no gain in being able to stop and start individually.

(b) All machines are such as are easily subject to heavy overloads, which if individually driven necessitates very liberally rated motors, whereas with mechanical drive the peaks average themselves out.

(c) It is cheapest, both in capital outlay and running cost. 
Table 3 gives particulars of typical electrically-driven machines forming this group.

It must be remembered that the power taken in all these processes varies materially with different classes of raw material: wood pulps require least, and rags and ropes, most power.

Paper machines. - These would be electrically. driven.
Calenders and cutters require speed variation, under conditions, however, which can generally be easily met by ordinary shunt control. The calender drive can be considered just as a machine drive, any one of the systems referred to being applicable to it.

Table 4 gives particulars of typical drives for finishing-department machinery.

TABLE 3.

Breaking, Beating and Refining-Electric Drives.

\begin{tabular}{|c|c|c|c|c|c|c|c|c|}
\hline \multicolumn{2}{|l|}{ Drive } & Size & $\begin{array}{l}\text { Shaft or } \\
\text { Roll }\end{array}$ & Drive & \multicolumn{2}{|c|}{ Motor Installed } & \multicolumn{2}{|c|}{ Tested Load } \\
\hline News breaker & .. & $23 \mathrm{ft} . \times 11 \mathrm{ft} .6 \mathrm{in}$. & $\begin{array}{l}\text { r.p.m. } \\
120\end{array}$ & Belt & $\begin{array}{l}\text { b.h.p. } \\
80\end{array}$ & $\begin{array}{l}\text { r.p.m. } \\
480\end{array}$ & $\begin{array}{l}\text { Duty } \\
1 \frac{1}{4} \text { tons } \\
\text { per hour }\end{array}$ & 60 to 80 \\
\hline $\begin{array}{l}2 \text { news breakers a } \\
\text { and pump }\end{array}$ & and chest & $23 \mathrm{ft} . \times 11 \mathrm{ft} .6$ in. & 130 & $\begin{array}{c}\text { Ropes and } \\
\text { belt }\end{array}$ & 175 & 480 & $\begin{array}{l}\mathrm{l}_{4} \text { tons each } \\
\text { per hour }\end{array}$ & 150 to 170 \\
\hline Rag breaker & $\cdots$ & $19 \mathrm{ft} . \times 7 \mathrm{ft} .6 \mathrm{in}$. & 120 & Belt & 50 & 500 & $\begin{array}{l}12 \text { cwts. ropes } \\
\text { and bagging }\end{array}$ & 41 to 48 \\
\hline Esparto potcher & $\ldots$ & $30 \mathrm{ft} . \times 9 \mathrm{ft}$. & 95 & Belt & 25 & 500 & Washing & 20 to 21 \\
\hline Sulphite breaker & .. & $13 \mathrm{ft} . \times 6 \mathrm{ft} .6 \mathrm{in}$. & 110 & Belt & 12 & 460 & $\begin{array}{l}4 \text { bales } \\
\text { furnish }\end{array}$ & 10 to 12 \\
\hline "Milne" breakes & r, 2 rolls & $32 \mathrm{ft} . \times 12 \mathrm{ft}$. & 80 & Gear & 70 & 530 & $\begin{array}{l}39 \text { cwts. } \\
\text { esparto }\end{array}$ & 52 to 60 \\
\hline " $\mathrm{B}$ and $\mathrm{J}$ " beate & . & $13 \mathrm{ft} . \times 6 \mathrm{ft} .9 \mathrm{in}$. & 144 & Belt & 50 & 500 & $\begin{array}{l}500 \mathrm{lb} . \\
\text { ropes }\end{array}$ & 45 to 50 \\
\hline "Bertram" beat & . & $20 \mathrm{ft} . \times 8 \mathrm{ft}$ & 150 & Belt & 40 & 600 & $\begin{array}{c}500 \mathrm{lb} . \\
\text { pulp }\end{array}$ & 20 to 30 \\
\hline Beater $\quad \ldots$ & . & $18 \mathrm{ft} .6$ in. $\times 9 \mathrm{ft}$. & 140 & Belt & 70 & 450 & Rags & 56 to 70 \\
\hline 2 beaters .. & $\cdots$ & $\begin{array}{l}13 \mathrm{ft} .6 \text { in. } \\
\times 6 \mathrm{ft} .9 \mathrm{in} .\end{array}$ & 160 & Ropes & 65 & 350 & Rags & 60 to 70 \\
\hline 4 "M and $S$ " tow & er beaters & $\begin{array}{c}4 \mathrm{ft} \text { roll } \\
4 \mathrm{ft} .3 \mathrm{in} . \text { tower }\end{array}$ & $\begin{array}{l}\text { C.S. } \\
180\end{array}$ & Ropes & 180 & 540 & Esparto & 160 to 180 \\
\hline $\begin{array}{l}\text { "M and S" towe } \\
\text { trator }\end{array}$ & r concen- & $4 \mathrm{ft} .3$ in. diam. & 184 & $\begin{array}{l}\text { Gear and } \\
\text { belt }\end{array}$ & 50 & 550 & Esparto & 35 to 50 \\
\hline News refiner & . $\quad \cdots$ & Walmsley & 320 & Belt & 150 & 480 & $\begin{array}{l}11 \text { tons per } \\
\text { hour. Usual } \\
\text { news }\end{array}$ & 110 to 150 \\
\hline Marshall refiner & $\cdots$ & $" B \& J "$ & 250 & Belt & 100 & 500 & $\begin{array}{l}\text { Esparto and } \\
\text { wood }\end{array}$ & 60 to 90 \\
\hline Disc refiner & $\cdots$ & Bertram & 200 & Belt & 60 & 500 & $\begin{array}{l}600 \mathrm{lb} \text {. per } \\
\text { hour rag wood } \\
\text { furnish }\end{array}$ & 40 to 45 \\
\hline Presspate & $\cdots$ & $4 \mathrm{ft} .6 \mathrm{in}$. & $\begin{array}{c}184 \\
(60 \mathrm{ft} . \\
\text { per } \\
\text { min. })\end{array}$ & Gear & 24 & 850 & - & 15 \\
\hline Presspate & $\cdots$ & $5 \mathrm{ft} .6$ in. & - & Gear & 28 & 700 & $\begin{array}{l}20 \text { cwts. wet } \\
\text { pulp per hour }\end{array}$ & 16 to 20 \\
\hline
\end{tabular}

The wet end represents no difficulty as it is simply a constant-speed drive. The various ways of driving the dry or variable-speed end form the main theme of this paper.

Finishing department.-Comprising the calendering, reeling, cutting and making-up of the finished paper. In most modern mills all these machines are already electrically driven and present no outstanding diffculties.

VOL. 59.
Selection of Motors.

As the driving shafts of many of the machines used in the paper mill run comparatively slowly (60 r.p.m. for cutters, 100 to 150 r.p.m. for beaters, etc.), the use of high-speed motors is not to be recommended. In many otherwise excellent installations motors have been installed with ridiculously small pulleys, or the introduction of a more or less noisy backgear, so as to enable a high-speed motor to be put in. Doubtless 
the competition to book the order has been the cause, but that can hardly be considered a sufficient excuse for setting up weak links in an expensive lay-out. Manufacturers would be well advised when submitting such schemes to give the purchaser alternative tenders, one the cheapest possible by using high-speed motors, and the other a recommended alternative with a lowspeed motor and a sound millwrighting drive.

A typical example of this is the cutter drives quoted in Table 4, 4-h.p. motors running at 180 to 360 r.p.m. These, which were installed in 1903 , have run perfectly,
Switchgear cannot be too good for the paper mill; the conditions of handling, hours of service, humidity of atmosphere, bleach fumes, etc., will soon make trouble otherwise.

Wiring in tubing and on the lead-covered system is of no use. Cab tyre sheathing stands up well if carefully erected, using separate insulators with ample gripping surface (preferably not ridged), or cleats. For three-phase work armoured cable, with sealing boxes on standard lines, is worth the slight extra outlay. Bitumeninsulated cables should not be used in the machine

TABLE 4.

Finishing : Electric Drives.

\begin{tabular}{|c|c|c|c|c|c|c|c|}
\hline Drive & Size & Speed & Drive & Mot & or Installed & Tested & \\
\hline Single-drum reeler & $\begin{array}{l}\text { in. } \\
72\end{array}$ & ft. per min. & Belt & $\begin{array}{l}\text { b.h.p. } \\
6\end{array}$ & 800 to 1000 & $\begin{array}{l}\text { Duty } \\
200 \mathrm{ft} .\end{array}$ & $\begin{array}{l}\text { b.h.p. } \\
\quad 4\end{array}$ \\
\hline 2-drum winder $\quad \ldots \quad \ldots$ & 100 & 1130 & Belt & - & - & 90 in. $16 \mathrm{oz}$ & $13 \frac{1}{2}$ \\
\hline 4-drum “ $M \& W$ " winder & 140 & $\begin{array}{l}273 \text { r.p.m. } \\
1000 \mathrm{ft} . \\
\text { per min. }\end{array}$ & Belt & 25 & 750 & News $1000 \mathrm{ft}$. & 23 \\
\hline Damper Schurmann & 112 & 600 & Belt & 6 & 1200 & - & 5 to 6 \\
\hline Friction calender . . & 72 & 70 to 210 & Gear & 35 & 300 to 900 & Rag browns & 30 to 35 \\
\hline Glazing calender, 5-roll .. & 80 & 150 to 300 & Chain & 25 & 400 to 1200 & - & 12 to 15 \\
\hline 2-plate glazing calenders.. & 36 & - & Belt & 8 & 600 & - & 4 to 8 \\
\hline $\begin{array}{l}\text { Coated paper calender, } \\
\text { 7-roll }\end{array}$ & 50 & 60 to 210 & Gear & 22 & 600 to 1100 & $\begin{array}{l}25 \text { in. wide } \\
180 \mathrm{ft} .\end{array}$ & 9 to 12 \\
\hline Super-Eck, 10-bowl $\quad$. & 96 & 50 to 400 & Gear & 50 & 400 to 800 & $240 \mathrm{ft}$. & 30 \\
\hline Super-Schurman, 10-bowl & 112 & 80 to 450 & $\begin{array}{l}\text { Jockey } \\
\text { pulley }\end{array}$ & 100 & 850 & 420 & 70 \\
\hline Ditto, 12-bowl $\quad$. $\quad$. & 72 & 60 to 400 & Belt & 70 & 450 to 650 & $\begin{array}{l}\text { Wall-paper } \\
375 \mathrm{ft} .\end{array}$ & 63 \\
\hline Ditto, Walmsley, 10-bowl & 130 & 30 to 600 & Belt & $\begin{array}{l}\text { A.C. } 15 \\
\text { and } 150\end{array}$ & $\begin{array}{l}1000 \text { and } \\
720\end{array}$ & News $600 \mathrm{ft}$. & 120 \\
\hline Single cutter and layer .. & 84 & 70 to 200 & Belt & $2 \frac{1}{2}$ to 4 & 190 to 500 & $70 \mathrm{ft}$. to $180 \mathrm{ft}$. & $1 \frac{1}{4}$ to $2 \frac{3}{4}$ \\
\hline Duplex cutter and layer.. & 120 & 80 to 160 & Belt & $4 \frac{1}{2}$ & 180 to 360 & $135 \mathrm{ft}$. duplex & $3 \frac{3}{4}$ \\
\hline Duplex cutter $\quad$. $\quad$.. & 72 & 100 to 200 & Belt & 4 & 180 to 360 & $\begin{array}{l}25 \text { in. boards } \\
200 \mathrm{ft} .\end{array}$ & $3 \frac{1}{2}$ \\
\hline $\begin{array}{l}2 \text { coating machines with } \\
\text { fans and reeler }\end{array}$ & 48 & $\begin{array}{l}\text { C.S. } 150 \\
\text { r.p.m. }\end{array}$ & Belt & 15 & 550 & About $120 \mathrm{ft}$. & 12 to 14 \\
\hline Guillotine $\ldots \quad \ldots$ & 48 & $\begin{array}{l}\text { C.S. } 250 \\
\text { r.p.m. }\end{array}$ & Belt & 4 & 1000 & 4 in. cut & $3 \frac{1}{2} *$ \\
\hline
\end{tabular}

* Momentary.

there being no noise, no fast-running belts, practically no wear and tear, but just a slow-running belt from a motor on a wall bracket to the driving pulley on the cutter.

The pipe-ventilated motor with a properly-run airinlet pipe is undoubtedly the best for paper mill conditions, as in all parts of the process there is either an abundance of dust, nap or water. There is no need for air-outlet pipes; the warm discharged air helps to heat the room.

\section{SWITCHGEAR AND WiRING.}

These two essential factors, which can so easily make or mar the installation, will only be dealt with briefly. houses, where the roof temperature is sometimes 130 or $150^{\circ} \mathrm{F}$.

Generally speaking, for both switchgear and wiring, there will not be much trouble if good mining practice is followed.

\section{RELIABILITY.}

All equipment, whether power-plant, individual motors, or machine drives, must be absolutely reliable. Paper mills run night and day, and obtain their maximum output by keeping the paper machines running with the minimum of "shut." A stoppage in main power plant, with the present system of engine-driven machines, of even half an hour does not affect the 
weekly output since the paper machine carries on, having sufficient reserve of prepared stock in the chest in front of it; on the other hand, on an electricallydriven machine the tripping of a circuit breaker, causing machine motors to shut down for just a few seconds, is fatal, as it entails washing down the wire, with attendant loss of time, output, and stock. This, to the paper maker, is one of the most vital factors in consideration of any scheme of power reorganization.

Generally speaking, the simpler the equipment is the better; electrical interlocks and foolproof safeguards can be easily overdone in this respect.

\section{Heating ReQuirements.}

Before any choice of power plant can be made, the heating requirements need thorough consideration.

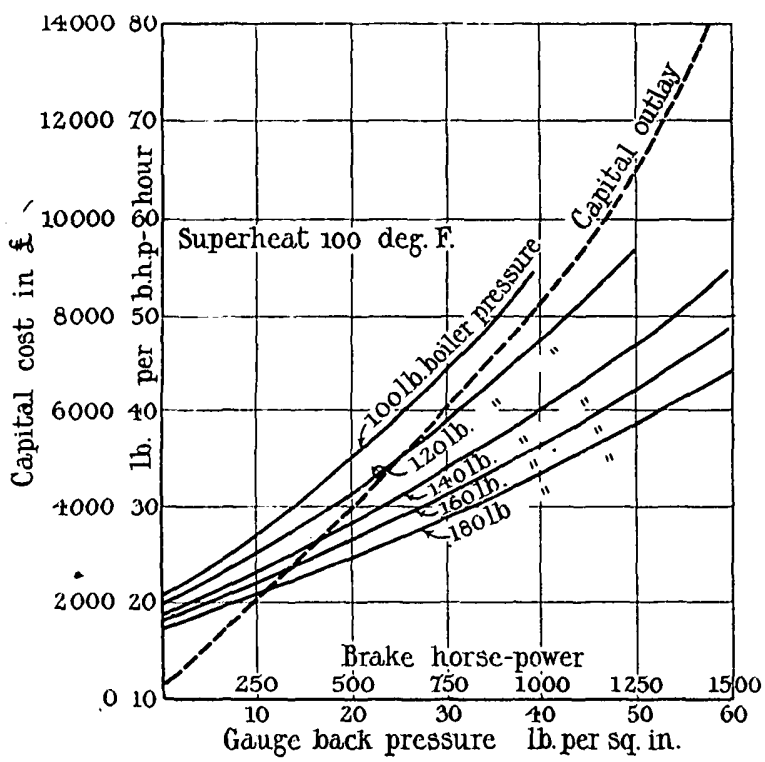

FIG. 2.-Back-pressure high-speed steam engines up to 1500 b.h.p.

Curves showing effect of boiler pressurc and back pressure on steam con sumption, also capital cost at 160/180-lb. boiler pressure and 15-lb. back pressure.

For drying the web on the paper machine, where there is a continuous draw of steam for drying purposes, the conditions are fairly simple. Actual tests have proved that $3 \frac{1}{2}$ to $4 \mathrm{lb}$. of steam are required for every pound of paper delivered on the reel, with the present system of cast-iron drying cylinders; roof heating in machine houses requires 0.2 to $0.5 \mathrm{lb}$. per pound of paper.

The digestion or boiling of rags, where the usual 8-ft. digesters are installed, averages out to a fairly steady draw for the boiling-house; esparto or straw digesters with their great capacity cause very considerable fluctuations in the demand for heating steam, which may easily upset all calculation unless the power unit is suitably installed.

The actual measurement of the steam used by an approved steam meter or isolation of a steam boiler taken over an extended period of normal working, together with a thorough knowledgc of the process and its requirements, is the only safe guide.

The pressure at which the heating steam is required also merits scrutiny; cases will often be found where by slight rearrangement of pipes, or the proper use of covering medium, the pressure can be appreciably reduced without any detriment to the process.

Fig. 2 shows the steam consumption with various degrees of back pressure; the gain by keeping this back pressure down to a minimum, particularly where medium-pressure boilers are being used, is obvious.

Where heating requirements fluctuate (as in esparto mills) the introduction of a heat accumulator or receiver between power house and mill will be found beneficial.

To reap the full benefit from the installation the exhaust steam must be utilized for every duty where heat is needed in the mill, whether it be direct steam, indirect steam, hot air, or hot water.

\section{Return of Heat to Boiler Feed}

Paper-mill practice lends itself well to this. No mill should, if properly laid out, even with the presentday system of condensing prime mover, have a hot-wcll temperature less than 150 to $160^{\circ} \mathrm{F}$. With a heateconomy lay-out this should increase to 180 to $200^{\circ} \mathrm{F}$., with resultant saving in smaller economizer lay-out needed. All condensed steam being pure, every possible drop should be returned to the hot-well, to save cost in treatment of feed water. With reciprocating engine prime movers there will be oil in the exhaust, which may be removed by an efficient oil separator.

\section{Steam BoIlers.}

Where the maximum of power from the heating requirements is desired, steam at 180 to $200 \mathrm{lb}$. pressure, with superheat to 550 to $600^{\circ} \mathrm{F}$., is advisable.

Many cases, however, will be found where lower pressures of 160 or even $120 \mathrm{lb}$. can be effectively used, thus enabling considerable saving to be made in the capital outlay. The pressure adopted depends on the requirements in quantity, and the pressure of heating-steam and power demands.

Superheat is absolutely essential to ensure dry steam for the heating requirements.

\section{TyPes of Powter Plant.}

For the purposes under consideration these are :-

(1) Back-pressure high-speed compound steam engine.

(2) Back-pressure horizontal compound drop-valve engine.

(3) Back-pressure steam turbine.

(4) Heat-extraction horizontal compound condensing steam engine.

(5) Heat extraction or bleeding condensing steam turbine.

(6) Utilization of existing prime movers with mixedpressure turbine, and other additional power units.

No particular system of prime mover can be said to supply the requirements of every type of paper mill. 
A typical one-machine equipment may be instanced :-

Boiler : $30 \mathrm{ft} . \times 8$ ft. 6 in., $180 \mathrm{lb}$., superheat to $550^{\circ} \mathrm{F}$., hand-fired.

Engine: Horizontal drop-valve compound 400 h.p., $15 \mathrm{lb}$. back pressure, driving four beaters, revolving boilers, dynamo for machine, and usual auxiliaries. Machine: Driven by 30-h.p. motor, speed range 8 to 125 feet per minute.

Output of paper : 70 tons weekly.

Over some years' operating, this mill averages about $16000 \mathrm{lb}$. of steam to every ton of paper made, a figure fully 30 per cent less than on mills with the usual condensing main engine and high-pressure machine engines.

In general terms, having settled the power required, the quantity of steam for heating, and the required pressure, then the right type of prime mover is the one the production of too much surplus heating steam and the demand for heating is practically steady, there can be no better system installed. It lends itself particularly to news, cheap printings, and certain classes of brown mills. If there are considerable variations possible in the heating demand, which do not require increase in horse-power, as in grass digestion, then it is not the system to adopt.

Where the conditions of power demand are such as to create too great a surplus of heating steam with this prime mover, or where the power demand fluctuates considerably, a combination with a similar unit working condensing, and electrically coupled together, or a heat-extraction condensing engine will probably fit the case better.

(2) Back-pressure horizontal compound drop-valve engine.-This is an adaptation of the modern low-speed

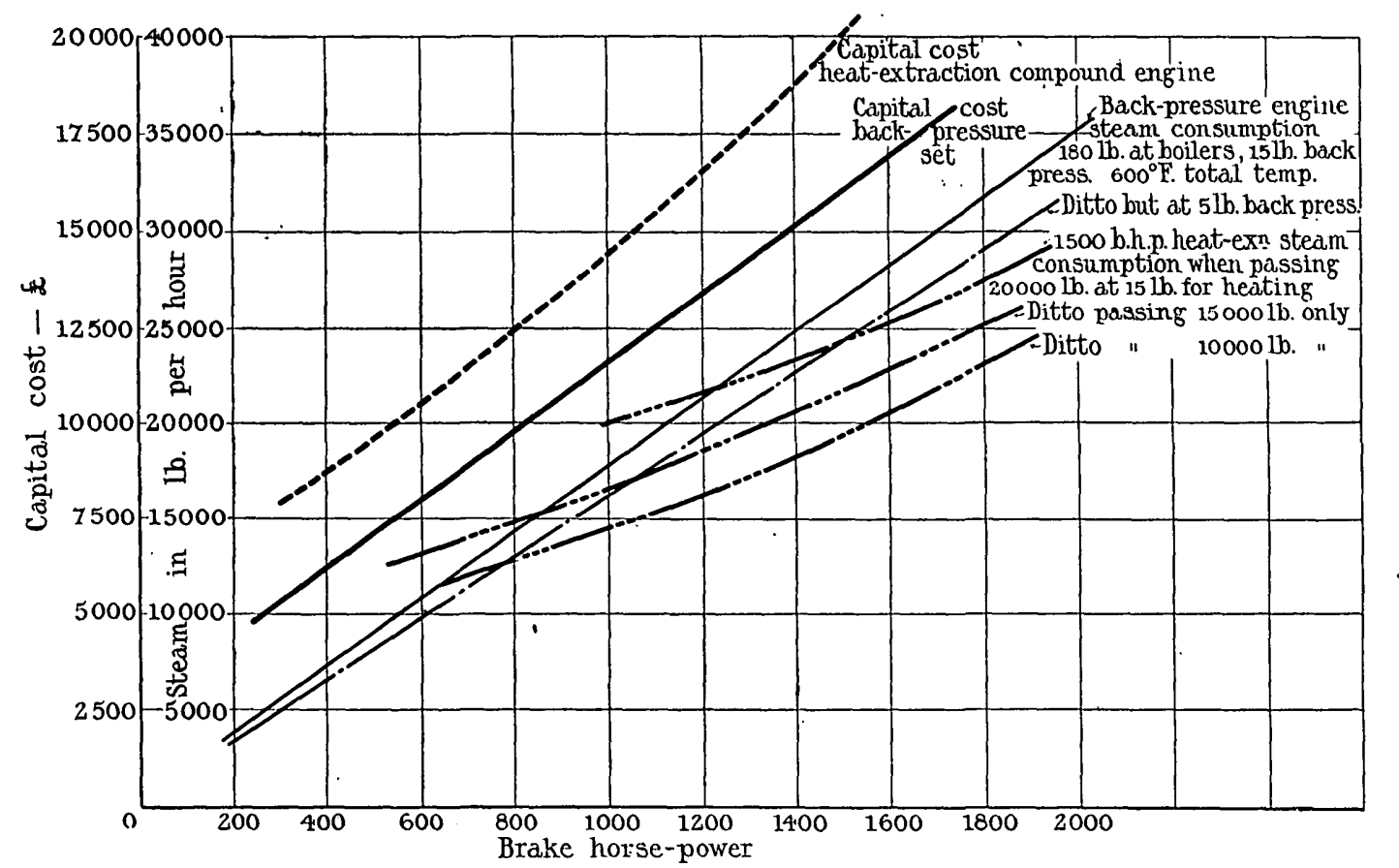

FIG. 3.-Steam consumption and capital cost of horizontal back-pressure and heat-extraction steam engines.

fulfilling these conditions with the minimum of capital outlay.

(1) Back-pressure high-speed compound engine.-This engine, coupled direct to the beater shaft by an efficient flexible coupling, or ropes, with the dynamo for machines and auxiliary drives direct or rope coupled, is materially the cheapest prime mover for heat-economy purposes, both in plant first cost, foundations, and housing. Its reliability has been abundantly proved. It is a type of engine which the paper-mill engineer thoroughly understands.

Fig. 2 gives the relative performance of this type of engine under different boiler and back pressures, together with an approximate idea of capital cost, including delivery and erection, for a direct-coupled drive to beater shafting.

Provided the horse-power required will not entail mill engine. As in type (1) it lends itself to either a direct-coupled or rope main drive, the dynamo being rope driven. The slower-running set entails more outlay in foundations and buildings, but this type of engine is just as reliable as any typical condensing mill engine, and preferred by some paper makers for that reason. For one or two machine mills requiring $400 / 1000 \mathrm{~h}$.p. this system has worked very well in actual practice. Fig. 3 is a curve of capital cost and steam consumption at 5 and $15 \mathrm{lb}$. gauge back pressure.

(3) Back-pressure steam turbine.-Any turbine is better than the reciprocating engine as regards freedom from oil in heating steam, but a back-pressure turbine otherwise has no advantages to justify its instalment, except perhaps in conjunction with another condensing heat-extraction prime mover.

The principal drawback to all these alternatives is 
that if the proportion of power and heating requirements be not accurately forecasted, supplementary heating by live steam by-pass, or the blowing to waste of surplus back-pressure steam is necessary. While with steady draw requirements of paper drying and roof heating this should be attainable, on the other hand it is bound to fail in connection with intermittent draws of heating requirement, as in grass digestion.

(4) Heat-extraction horizontal compound condensing steam engine.-This comprises a drop-valve high-pressure cylinder of more or less orthodox type, a receiver from which the heating steam is tapped at any predetermined pressure, and a uniflow low-pressure cylinder to attain the utmost power from the condenser. It fears it has too great a rival in the bleeding turbine ever to have much success.

(5) Heat-extraction or bleeding condensing turbines.For those mills where the demand for heating steam fluctuates, and particularly where it is required at different pressures, such as esparto mills, this system is undoubtedly the best.

The steam, containing no oil, is perfect as a direct or indirect heating medium.

The steam consumption depends, of course, on the quantity and pressure of draw-off. Fig. 4 gives typical curves for a $1000-\mathrm{kW}$ unit with different pressures and quantities of steam for heating.

The means of driving do, however, justify further

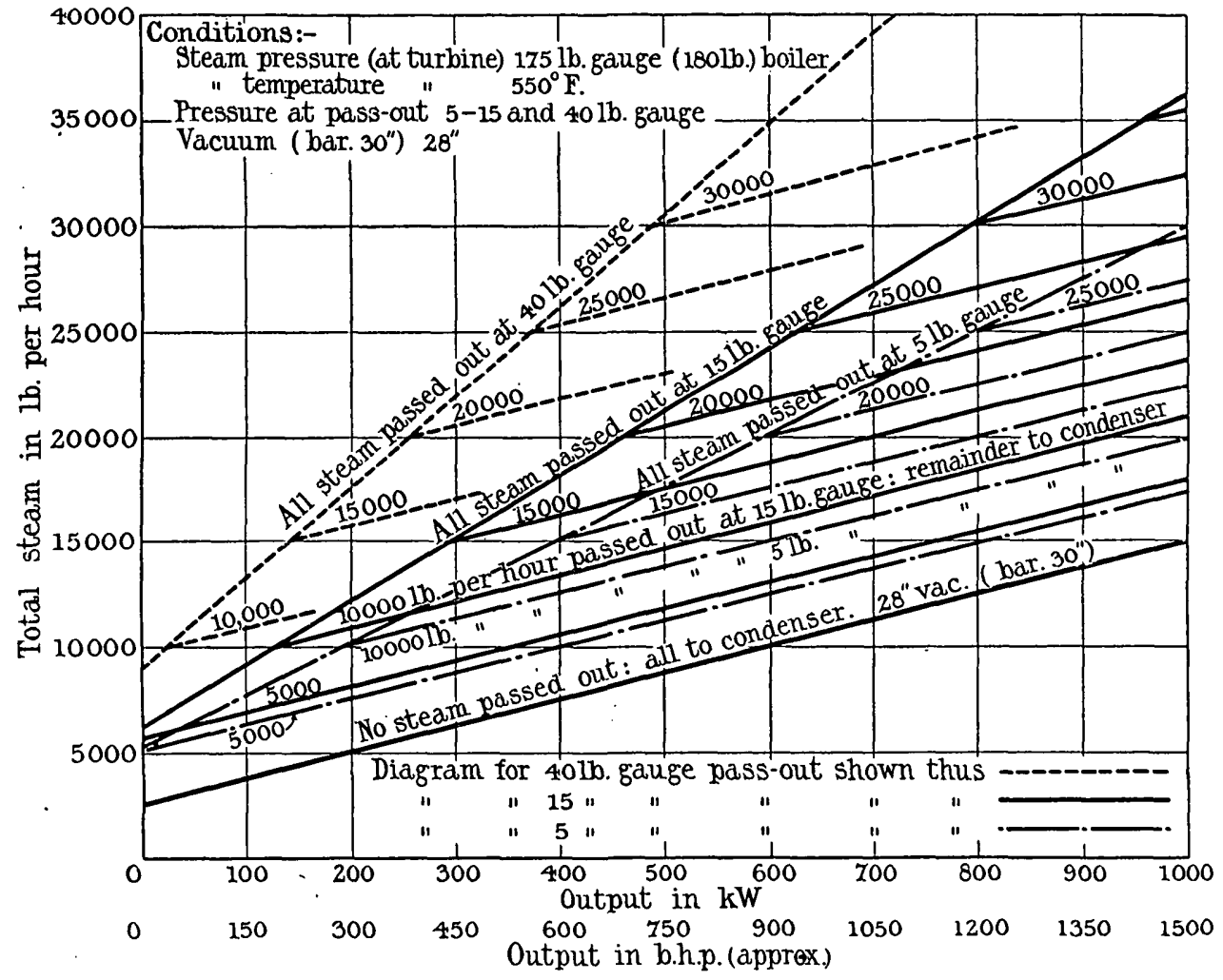

FIG. 4.-Steam-consumption diagram for $1000-\mathrm{kW}$ geared pass-out turbo-generator.

lends itself to direct drive as before, and provides a means of obtaining the extra power required for preparation and beating without an overplus of heating steam being provided. Such an engine, therefore, would lend itself to the requirements of a rag or fine mill. It does not, however, readily provide for bleeding at different pressures simultaneously, and has not as yet been installed to any great degree in this country. Its reliability would be just as good as that of types (1) or (2), and a direct shaft drive, without the cost of the electrical equipment, would help it.

Fig. 3 gives the approximate capital cost of such engines up to 1500 b.h.p. and the steam consumption of a 1 500-b.h.p. engine at different " pass outs."

Whilst it is a most interesting proposition, the author consideration. If we are to get the best results from the steam, a turbine speed (depending on type) of 3000 to 7000 r.p.m. is essential.

The following are four possible drives:-

(a) Through single or double reducing gear, and ropes, or direct to shaft.

(b) Direct coupled to alternator.

(c) Through reducing gear to drive alternator.

(d) Through reducing gear to drive direct-current dynamo.

System (a) gives the cheapest capital outlay and, provided a straight main drive is available, more economical running due to cutting out electric losses. There is, however, the question of reliability. Is one 
turbo set sufficiently reliable (without a stand-by) to run a paper mill for 132 hours every week, without any interruption of running time either due to turbine gear or drive?

The author's view is that while no advantage is to be gained by the driving of beaters and refiner electrically, and while there is certainly a considerably greater first cost incurred, the better way to install turbines in paper mills is in conjunction with complete mill electrification, including beaters and refiners. Then, even if no stand-by be installed at the time, it can always be added at a later date without scrapping any of the lay-out; further, it enables possible mili development to be better provided for.

As regards the three alternatives $(b),(c)$ or $(d)$, each has its known good points; the direct coupled alternator cuts out the gear, at the expense of possibly lower turbine efficiency and possible electrical trouble on such a high-speed unit.

The perfection to which geared turbines have now been developed, the undoubted advantages obtained by running the turbine at the most economical steam speed, and the use of standard designed medium-speed alternators or dynamos are, the author considers, more than sufficient to justify the extra expense incurred in such a combination.

(6) Utilization of existing prime movers on heateconomy lines.-The question of capital outlay, if nothing else, makes the consideration of any scheme whereby the plant standing at a low value in the books can be utilized on these lines, of first importance.

There are, broadly speaking, two ways :-

(a) The generally accepted principle of putting the present condensing engines on to a back pressure, letting them drive what they will of the main drive, and utilizing all surplus steam other than that taken for heating purposes for driving a low- or mixed-pressure turbine. This turbine would provide electric power for the driving of the paper machines, and all other electrically driven plant, and such drives as would have to be taken off the main engine due to its running under back pressure.

(b) The other alternative would be to let the main engine run entirely on back pressure, utilizing all its steam for heating purposes and supplying the extra power required by means of direct-coupled high-speed or other set working condensing.

Propositions on these lines show up very well in capital outlay, but the condition of the existing plant must be most carefully gone into before making a decision, particularly if it is a question of adding the turbine to work in conjunction with the existing plant, which may be approaching the end of its useful life.

\section{System OF SUPPLY.}

In practically all early mill installations direct current was installed so as to obtain the speed range necessary for many of the drives. As paper mills are fairly compact lay-outs transmission difficulties do not arise, 220 volts being mainly used.

The modern direct-current motor being such a reliable article, the author considers that, if beating and refining plant be not electrically driven, direct current should still be chosen. Where, however, the whole mill is to be electrified, alternating current should be selected, particularly if the commutator motor substantiates its present promise.

In deciding an alternating-current system the question of frequency immediately arises. Generally speaking, 50 periods has now been standardized throughout the country for three-phase power equipments and, without material reasons for departure from such a standard, it would appear unwise to adopt in the paper mill any other frequency, particularly if there is any prospect of being able to get a supplementary or stand-by supply from an outside source.

The periodicity of 25 , however, does exceedingly well for paper-mill drive. In the matter of millwrighting it enables direct-coupled motors to be installed to suit the low-speed drives common to the paper mill, without the first cost being abnormal. It also has advantages in keeping up both efficiency and power factor, thereby saving both in capital outlay for the generating plant and the wiring system.

\section{Electric Driving of the Paper Machine.}

The reasons for converting the paper machine from individual engine drive to electrical have already been stated.

The paper machine is really a group of machines interlinked, forming a continuous process in the manufacture of the paper sheet. A part, known as the "wet end," runs at constant speed and practically constant load for all callipers of paper made by the machine. The other, called the "dry end," has to vary with the calliper of sheet made.

The shafts to be driven, taking the Fourdrinier machine, are :-

One couch or wire.

One to three presses.

Two or three sets of drying cylinders.

Possibly a set of intermediate or smoothing rolls.

One to four stacks of calenders.

Reeling frame.

In other words, from 5 to 13 shafts, depending on the class and output of paper to be made. These various shafts are coupled together with belts or ropes.

As the web shrinks in the process of drying, it is necessary to have very fine means of regulation between the various sections. In early machines the regulation was effected by adding pieces of felt, called "bulking," to the pulley rims to increase the diameter. Modern practice has been to use either expanding rope pulleys or, which is more usual, taper belt pulleys with finethreaded belt shifters, to run the belt in any desired position.

\section{HORSE-POWER REQUIRED.}

Wet ends vary from 10 h.p. on narrow low-speed machines up to 350 to 400 h.p. on the latest "news" machines with a refiner on the back shaft.

Dry ends vary from 20 h.p. up to 350 to 500 h.p. on fast " news" machines. 
Requirements for Successful Drive.

(1) To give the speed-range essential for the paper maker to manufacture the various callipers and qualities of sheet. The variable high-speed steam engine has a working range of 9 to 1 , which has satisfied all requirements without the need of any change-speed gears, except on machines where an exceptional range of "makes" is required.

In a considerable proportion of cases a range of 3 to 1 for actual paper-making is ample; where extreme ranges are called for, the paper maker can often so arrange his "makes" that a change-speed gear will give the effective range without an abnormal and correspondingly costly motor equipment. A 3 to 1 shunt control, say, can give 30 to $90 \mathrm{ft}$., and 80 to $240 \mathrm{ft}$. per min., a total range (allowing a working overlap) of 8 to 1 with a simple shunt-wound motor. Such a change gear is effectively provided by a belt drive, the pulley ratios being so calculated that the one belt can be used for either fast or slow drive.

(2) To run the machine continuously at low speeds for warming up, washing felts, dryer scraping, trueing up of presses, and possibly buffing of rolls. Generally speaking, it will be found that the conditions are more severe in this respect in the one- or two-machined oldfashioned mills. In the larger and more modern layouts, the universal practice nowadays is to do all roll buffing out of the paper machine on a special buffing machine.

(3) To provide a satisfactory start-up from cold.

(4) To give the minimum increase of speed at any point to point on the control. The paper maker attaches the greatest importance to this factor; a jump from, say, $200 \mathrm{ft}$. to $220 \mathrm{ft}$. might necessitate making that particular order at $200 \mathrm{ft}$., as $220 \mathrm{ft}$. per min. would be too fast, whereas at $210 \mathrm{ft}$. the same sheet could have been turned out and $\mathbf{5}$ per cent more output obtained.

(5) The advances in speed from point to point should be as equal as possible over the whole range.

(6) The speed must remain constant. A slowing down or speeding up of machines after the proper speed has been obtained causes overweight or underweight of finished paper.

(7) The method of control must be as simple as possible ; the nearer an approach is made to the old variable cone pulley on the variable-speed machine engine, where the machinist has simply one hand-wheel to turn, the better.

(8) Absolute reliability of action, which obviously includes not only motors, but every detail of the equipment from supply to machine driving shaft.

(9) If by the adoption of the multi-motor drive for the dry end, a reduction on the amount of "broke" can be guaranteed, it is a very appealing argument to the paper makers.

(10) The point of control to be preferably where the machinist has a full view of the running machine.

\section{Methods of Drive.}

The driving of the "dry end " can be either :-

Single motor: Taking the place of the engine, and retaining the present taper belt pulleys. It may be one of the following alternatives:- (a) Shunt and series control, d.c. motor, from mill supply.

(b) Shunt control, d.c. motor, from mill supply.

(c) Potentiometer control, d.c. motor, from a separate dynamo.

(d) Potentiometer and shunt control from a separate dynamo.

(e) Ward-Leonard control from mill supply.

(f) Booster control from mill supply.

(g) Alternating-current commutator motor from mill supply.

(h) Direct- or alternating-current constant-speed motor with variable oil gear.

Multi-motor: A motor being connected to each of the shafts from couch to reel, thus dispensing with the taper pulleys and clutches.

(a) Direct-current motors from mill supply with either a mechanical or an electrical interlock between each section of the complete drives.

(b) Alternating-current commutator motors, with or without an interlock between each draw.

(c) Constant-speed a.c. or d.c. motors with variable oil transmission.

\section{Consideration of Alternative Systems.}

(a) Shunt and series control.-The earliest equipments used were on these lines; the variations in speed on series control were the cause of endless complaints, and undoubtedly much of the prejudice existing in the older school of paper makers to-day to the electric drive arises from bitter experiences with these early equipments.

(b) Shunt control.-This simple system, provided that a range of not more than 3 or $3 \frac{1}{2}$ to 1 is required is excellent. The usual drum-type control gear is used with series resistances amply rated to allow for slow running when warming up; on the barrel, say, $\mathbf{4 4}$ shunt points are provided for the 3 to 1 range; the motor is protected by the usual control pillar with circuit breakers interlocked with the controller barrel. By providing an auxiliary 15-point shunt regulator on the control panel proportioned so that its total resistance is equal to that between any set of points on the controller barrel, 660 shunt-control running speeds are possible. The author has used this device for some years in paper-mill work, with excellent results.

(c) Potentiometer control from a separate dynamo.By this control a stable speed-range of 6 to 1 or 7 to 1 is attainable. The supply is from a separate dynamo driven preferably by ropes from the main power unit, thereby cutting out the motor-generator losses of the Ward-Leonard system. The whole main control is by one hand-wheel, giving 50 speeds, with the addition of the auxiliary fine-regulator controller of, say, 15 points, a total number of steps of, say, 750. This system has proved very reliable in practice.

(d) Potentiometer and shunt control (see Fig. 5).-A combination of the systems $(b)$ and (c), which will give a speed range of 10 or 12 to 1 . It will be noted that the one hand-wheel provides for the first part of its range 36 points on potentiometer control, and at 
the higher speeds 15 points by shunt control. The 15point fine-regulator device is again used, giving a total of 765 steps in speed. The simplicity of this lay-out,

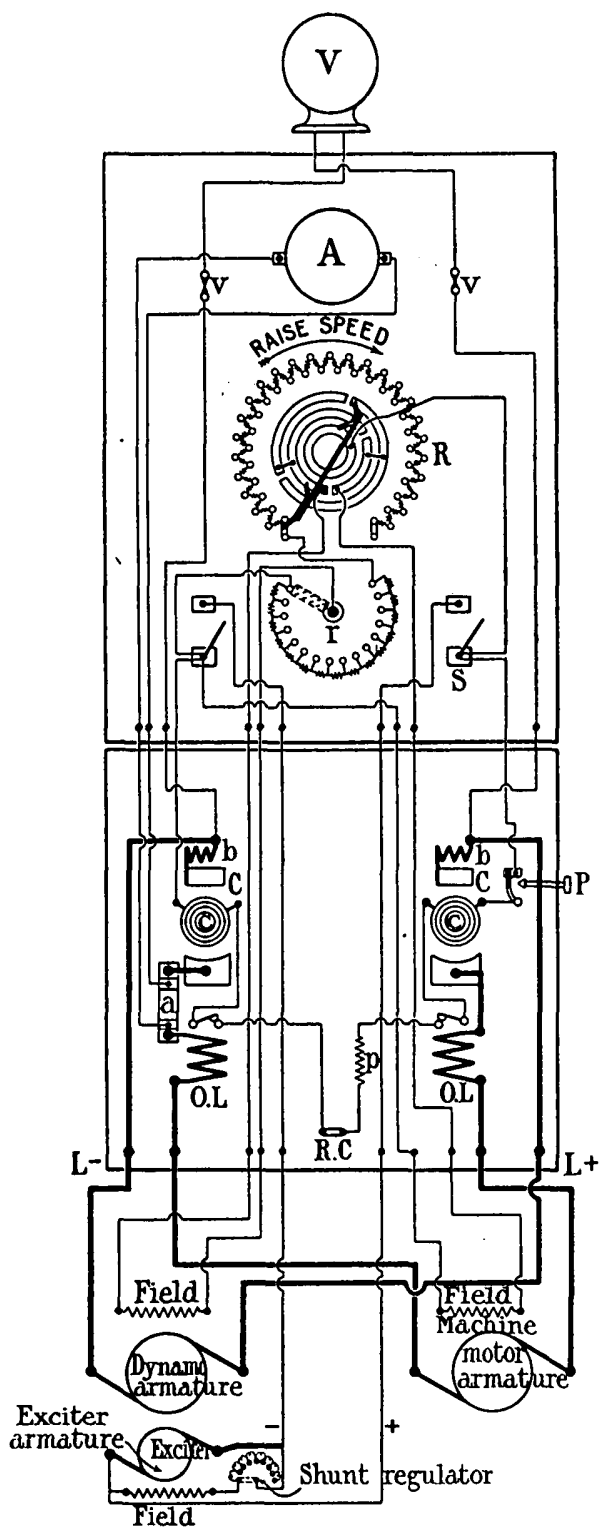

Fig. 5.-Combined potentiometer and shunt control switchgear for paper machine.

A Ammeter.

a Ammeter shunt.

Hand-operated circuit breaker, mechanically interlocked with $R$ so that rircuit breaker can only be closed when $R$ is in the "minimum voltage" position.

c Circuit-breaker coils.

OL Overioad release.

P Push-button

Permanent resistance for $C$.

potentlometer and shunt regulator.

$r$ Auxiliary potentiometer regulator.

Field break switch.

Voltmeter.

RC Link for remote control press-button if required.

together with the large range of speed possible by it, are particularly noticeable.

(e) Ward-Leonard system.-The driving of the separ-

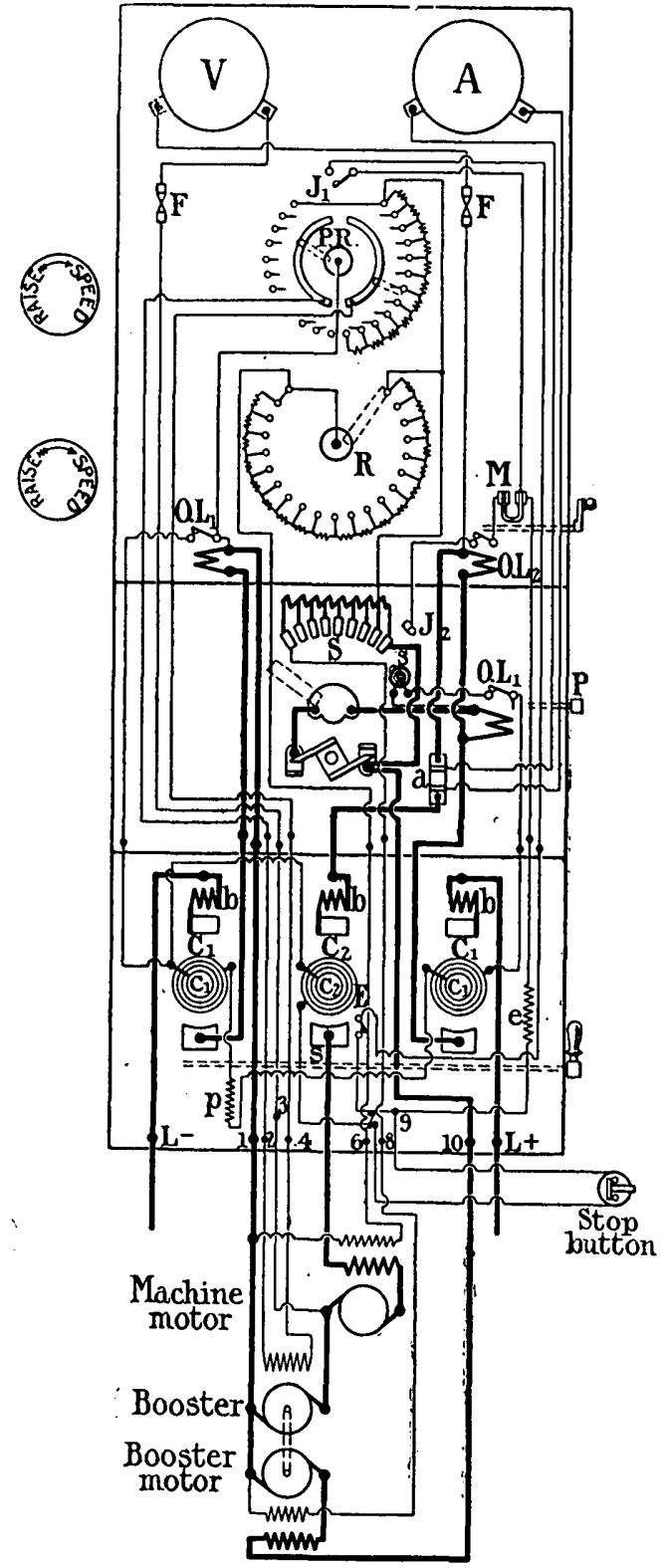

FIG. 6.-Booster-controlled paper-machine switchgear.

A Ammeter.

Ammeter shunt.

b Blow-out coils.

C1 Hand-operated circuit breaker mechanically interlocked with $S$ and electrically interlocked with C2.

lectrically-operated circuit breaker mechanically interlocked with $S$, $\mathrm{PR}$ and $\mathrm{Cl}$.

c1 Circuit-breaker coll.

C2 Circuit-breaker coil.

Economy switch, closed when C2 is open.

e Economy resistance.

J1 Adjustable interlocking switch closed when PR is in position corre. sponding to negative boost equal to line voltag

J2 Interlocking contact (makes circuit of $\mathrm{C} 2$ when $\mathrm{S}$ is full on) $M$ Master switch with re-setting device.

OL1 Overload release (plain).

P Push-button release for $\mathrm{C1}$.

p Permanent resistance.

PR Reversing potentiometer regulator for booster field.

$R$ Shunt regulator for machine motor, mechanically interlocked with $P R$ Starter mechanically interlocked with $\mathrm{C} 1$ and electrically interlocked with C2.

s Starter " no-volt" coil 
ate generator and exciter for each machine by a motor from the main supply, instead of mechanically by belt or ropes from the engine, converts system $(d)$ into what is termed the Ward-Leonard system. Such a system can obviously work on either alternating or directcurrent supplies. Its drawbacks are the extra capital outlay incurred and the running losses due to the motorgenerator.

(f) Booster control (see Fig. 6).-This system has been developed to overcome the drawbacks of the Ward-Leonard control. Provided the main supply is direct current and the voltage of the main supply does not exceed, say, 250 volts, it is satisfactory. The main motor is wound for double the mill supply voltage, and the speed-range then obtained by the variation of boost either up or down on the booster, which is only half the size of the Ward-Leonard booster, thereby saving in both capital and running costs. The range of speed may be up to 12 to 1 . The control, it will

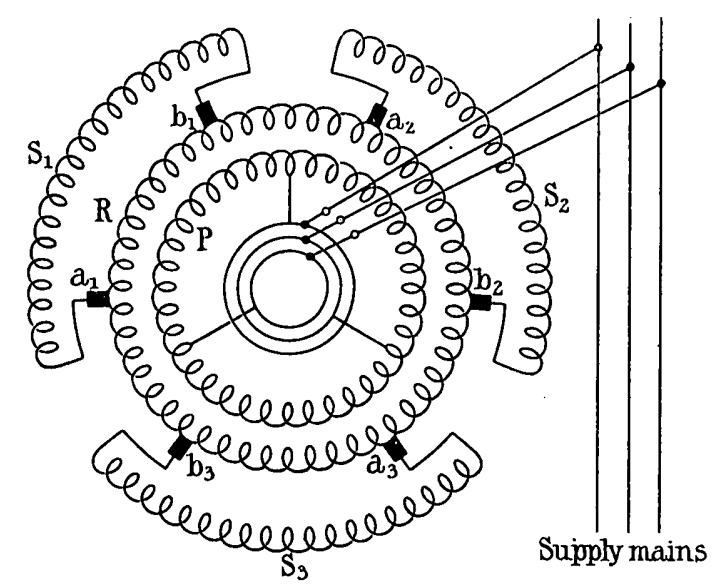

Fig. 7.-Diagram of connections of an a.c. commutator motor.

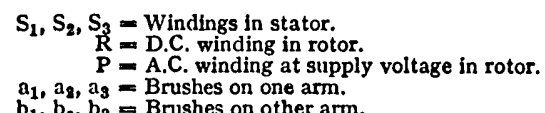

be noted, is by two hand-wheels, one for the booster field, and the other for the machine motor field; the use of two 25-point regulators will give 625 running speeds.

(g) Alternating-current commutator motors. - Variablespeed a.c. commutator motors have for several years been on the market with series characteristics, but only during the past few years has a practical machine with a shunt characteristic been developed by one or two makers, such as the British Thomson-Houston Company in this country, and the Allmanna Swenska Elektriska Aktiebolaget, Sweden.

These commutator motors provide a speed range of 3 to 1 with efficiency and power factor little less, if any, than those of the ordinary induction motors. As this speed-range can be increased by series control to 6 or 10 to 1 for starting purposes, it gives the motor all the advantages attained by the d.c. shunt-control motor, with one great improvement, i.e. the speed-range being attained by moving the position of the brushes on the commutator the variations in speed are gradual ; it is simply a question of having a slow-moving gear attached to the brush arm to obtain the most perfect degree of fine regulation.

The principle can be readily followed from Fig. 7. The rotor is double wound, one winding $P$ being

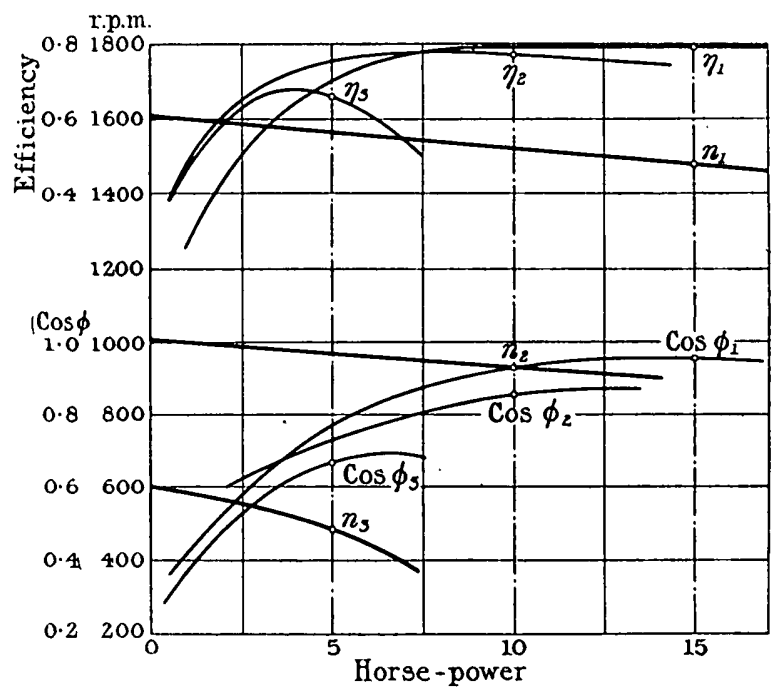

Frc. 8.-Load characteristics for three brush-positions on a three-phase commutator motor.

connected through the slip-rings on to the supply mains ; the other winding $\mathrm{R}$ is an ordinary d.c. winding with a commutator. The windings on the stator, $S_{1}, S_{2}, S_{3}$ are coupled to the brushes $a_{1} b_{1}, a_{2} b_{2}$ and $a_{3} b_{3}$. The regulation of speed by moving the brushes can be performed at the motor; either mechanically

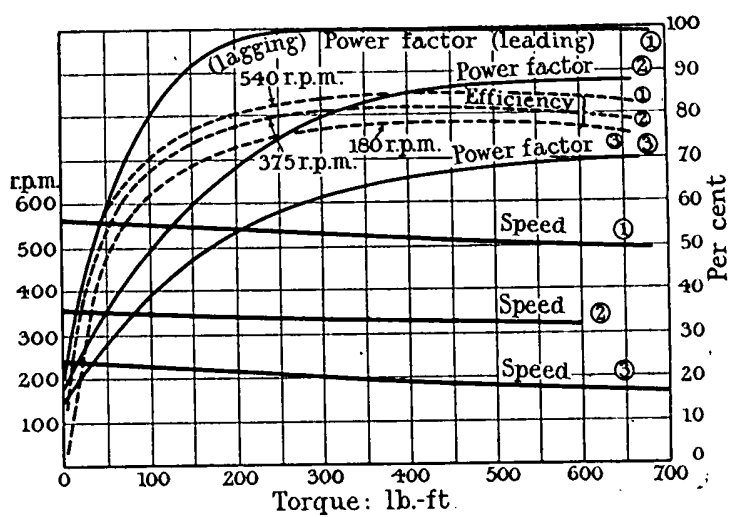

Fig. 9.-Power factor, speed and efficiency curves of a three-phase B.T.H. a.c. commutator motor at 400 volts, $50 \sim, 180$ to 540 r.p.m.

from a distance by means of rods or chain, or electrically through a small motor and gear. The brushes $a_{1}, a_{2}$ and $a_{3}$ are all moved together, similarly $b_{1}, b_{2}$ and $b_{3}$.

If the brushes $a_{1}, a_{2}, a_{3}$ and $b_{1}, b_{2}$ and $b_{3}$ are on the same bar, the motor runs as an ordinary induction motor.

The load characteristics of a 15 to 6 h.p. (Swedish 
Electric) motor are given in Fig. 8. Considering the relatively small size of the machine referred to, the results are very good.

Similar curves for a larger machine (B.T.H.) of 50 h.p. are plotted in Fig. 9. The high efficiency and power factor, the latter especially at the above synchronous speeds, are worthy of note. Readings are given for three speeds, but any number of speeds could be obtained by altering the brush position.

There are, undoubtedly, great possibilities before this type of motor in the paper mill, not only for the machine drive, but also for all other duties requiring variable speed, such as calenders, cutters, etc. It has already been successfully applied to machine drives in Scandinavia and this country; and several others particularly those where a maximum running speedrange of 3 to 1 is all that is desired.

(h) Variable oil gear.-Whilst not an electrical device, the possibilities of a variable-speed drive, such as the Williams-Janney oil gear provides, in conjunction with a constant-speed motor, or driven off the main shaft, must be mentioned.

This oil gear gives a gradual rise in speed and, provided proper cooling of the oil is arranged, the speed keeps absolutely steady. The sole control is by one small hand-wheel. It has not yet been used for a machine drive in this country so far as the author has been able to ascertain, but there is no reason why it should not prove quite effective. The possible objections are the losses in efficiency in the oil pump and oil

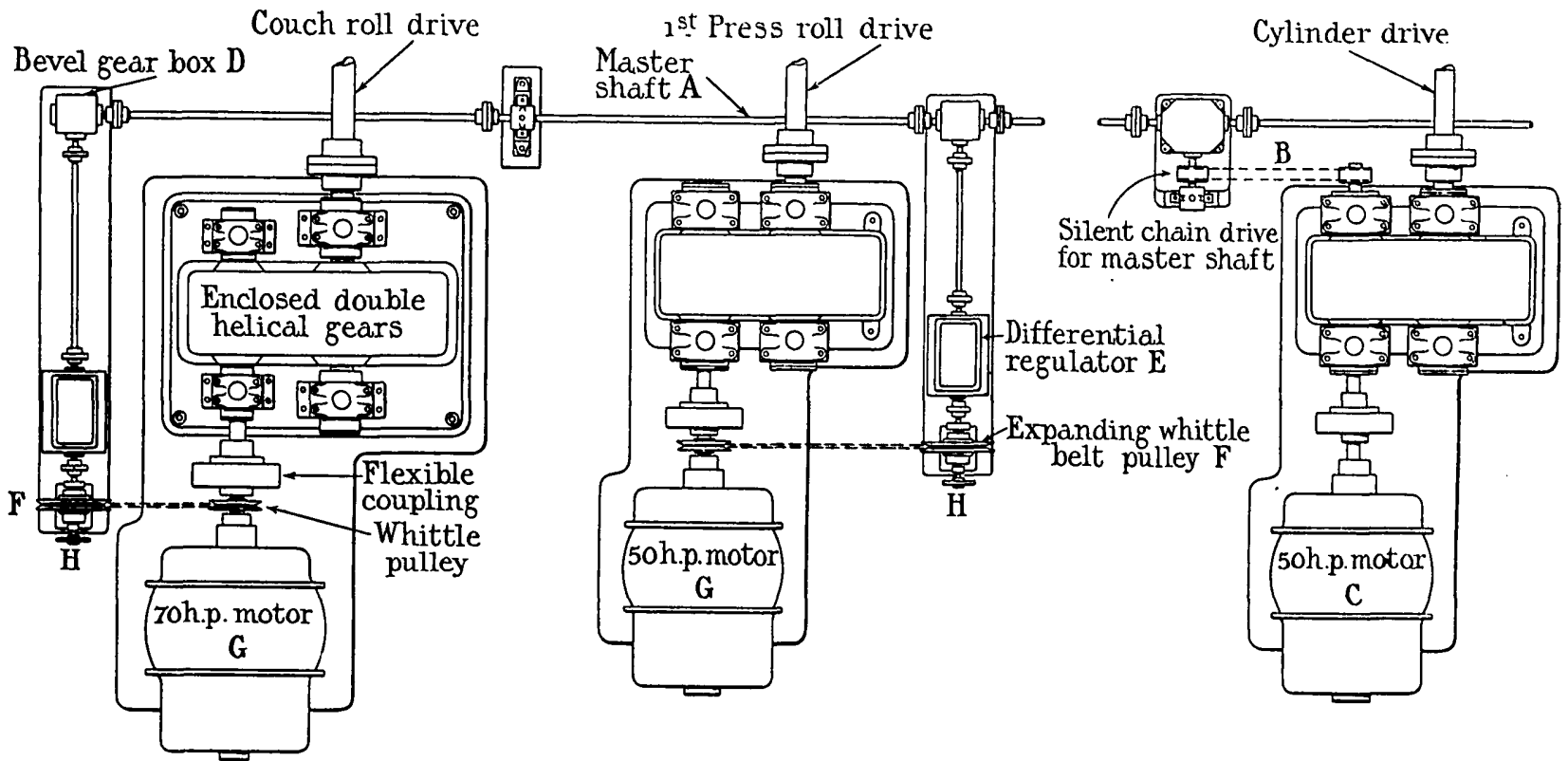

Fig. 10.-Diagram of the Harland patent speed interlock for 140 -in. paper machine, at 300 to $700 \mathrm{ft}$. per min.

are on order, both for single- and multi-motor drives.

The possible objections to the system are :-

(a) The double-wound rotor is a complication which may eventually result in failures, due to continuous running and consequent lack of time for systematic cleaning.

(b) The commutator necessarily becomes rather large in diameter, and at high speeds may not prove as good in commutation as the present-day d.c. machine.

(c) The first cost of the motor will be higher than in the d.c. shunt system, though probably little, if any, dearer than the complete WardLeonard system.

(d) It has not yet had the extended trials on which opinions of d.c. systems are based.

Its other advantages, however, make this type of motor worthy of very careful consideration for a machine drive where a three-phase supply is installed, and motor, amounting to about 20 per cent, and the possibility of trouble arising in time due to wear of the working parts when running constantly night and day.

\section{MUlti-Motor Systems.}

(1) Direct-current motors, with shunt control.-This system was first tried some 20 years ago, but considerable difficulties were found in keeping the various sections of the machine in proper relation to each other at different speeds, motor temperatures, etc. Any multi-motor system, to be satisfactory, must provide absolutely constant speeds between the various " draws," otherwise excessive "broke" will result. Mr. R. Harper, a leading Scottish paper-mill engineer, has spent many years in investigating and experimenting on this subject.

(2) Direct-current systems with interlocks.-There are several systems now on the market, such as :-

Harland patent speed interlock.

General Electric Co. (U.S.A.).

American Westinghouse.

Metropolitan-Vickers.

British Thomson-Houston 
The Harland system is a combination of mechanical differential and electrical interlocks. Fig. 10 gives details of three units of such a drive. The lay or master shaft A runs the full length of the machine, being driven by means of the chain $B$ from the cylinder-drive motor $C$, its speed therefore varying with the speed of the drying cylinders.

For every other section of the machine to be driven in step with the dryers there are separate drives, Fig. 10 just showing the couch or wire drive, and the first press drive. Each of these drives comprises a set of enclosed bevel gears $D$ driving a small shaft terminating in one half of the differential regulator $E$. The other side of the differential is driven by the expanding Whittle belt pulley $F$ from a small pulley on the motor shaft by a standard Whittle belt, which operates only the shunt regulator.

The differential operates a shunt regulator, the blade being connected to the housing of the differential. This regulator controls the adjoining section motor $\mathrm{G}$. If the lay shaft $A$ and the motor $G$ are not exactly in step the differential will revolve clockwise or anticlockwise, and will operate on the shunt field of the motor $G$, raising or lowering its speed until the synchronous speed is attained.

The expanding Whittle belt pulleys $F$ enable variation to be made by the machinist in the "draw " between individual sections. This can be done either at the back of the machine, by means of hand-wheel $\mathrm{H}$ as shown, which is the equivalent of present-day practice with taper pulleys and belt shifters or, if desired, operating shafts could be carried through to the front of the machine by simple gearing.

The speed of the machine as a whole is regulated from a control board placed in a central position, which affects all the motors simultaneously.

The simplicity by which the whole machine or any individual section can be varied in speed will be obvious from this brief description.

An experimental Harland equipment has been in operation in this country for over five years at speeds up to $250 \mathrm{ft}$. per min., and in January last at Laurentide, Canada, a large fast-running machine was started, which is running at over $800 \mathrm{ft}$. per min. very satisfactorily. The actual running results prove that this system can give all that is required by the paper maker for the drive. There is a slight tendency to hunt on the experimental equipment, due doubtless to backlash in the interlock, but it does not appear to be detrimental to the manufacture of the sheet.

The General Electric Co. (U.S.A.) system has been fitted to a fast-running news machine at the Crown Willamette Paper Co., West Lynne, Oregon, which started up about November 1920, and is running at a speed of 600 to $700 \mathrm{ft}$. per min. It is purely an electrical system ; a d.c. motor and a synchronous a.c. motor driven by taper cone pulleys are applied to each section shaft, the function of the synchronous motors being to run in step with the master motor and keep the sections relatively in step, the section draws being attained by the taper pulleys. All the means for keeping the various sections in correct step are electrical.

At the Mead Paper and Pulp Co., Chillicothe, two 154-inch machines are now being installed with this system, the particulars being :-

Speed range, 80 to $500 \mathrm{ft}$. per minute.

Estimated output per 24 hours, $80000 \mathrm{lb}$.

\begin{tabular}{|c|c|c|}
\hline & D.C. Motor & $\begin{array}{l}\text { A.C. Synchronous } \\
\text { Compensator }\end{array}$ \\
\hline Wire & $\begin{array}{l}\text { h.p. } \\
50\end{array}$ & $\begin{array}{l}\text { h.p. } \\
10\end{array}$ \\
\hline 3 presses each & 35 & 10 \\
\hline 2 section dryers each & 35 & 10 \\
\hline 2 "Stacks" calenders each. . & 50 & 10 \\
\hline Reel and rewinder $\quad \ldots \quad \ldots$ & 20 & - \\
\hline
\end{tabular}

A total of 345 h.p. in nine d.c. motors, and 80 h.p. in eight a.c. motors per machine (see World's Paper Trade Review for 21 January, 1921.)

The American Westinghouse have a machine running on their system at Gould Paper Mills, Lyon Falls, N.Y., which was started in November 1919 ; this also is a purely electrical system, being a combination of d.c. and a.c. interlocks.

The Metropolitan-Vickers Co. have recently developed a system which, in place of the longitudinal lay shaft and mechanical differential of the Harland system, has an electrical differential. It is claimed for this system that hunting can be entirely eliminated. There are not yet any systems in operation.

The British Thomson-Houston also has perfected a control which appears to have good possibilities, but which has not yet been actually tried on a paper machine. A particular advantage of the system is that it is applicable to either d.c. or a.c. commutator motors.

(3) Alternating-current commutator motor.-This type, providing as it does for speed-changing without jumps, will suit very well for a multi-motor drive. The adjustment between draws when once the motors have warmed up should be fairly simple. So far, the author cannot find any trace of machines so driven, although some are now under construction.

(4) Variable oil gear.-The driving of each shaft of the machine by a constant-speed (say, squirrel-cage) motor through an oil gear is also perfectly feasible. When the oil is at a constant temperature there will be no change of speed, provided the motor speed remains constant. The adjusting of the draws between the drives would be as simple as with the present taper belt pulleys. By fitting the same gears throughout, one spare unit would provide against gear trouble.

\section{Choice and Scope for Machine Drives.}

Table 5, which has been prepared with the help of the Paper Makers' Association of Great Britain and Ireland, gives particulars of practically all machines now electrically driven in this country. It will be noticed that the total is only 21 machines. When one considers that there are over 500 paper machines in the British Isles alone, the possibilities for development 
TABLE 5 .

List of Electrically Driven Paper Machines in the British Isles.

\begin{tabular}{|c|c|c|c|c|c|c|c|c|}
\hline \multirow{2}{*}{$\begin{array}{c}\text { Machine } \\
\text { Width } \\
\text { In. } \\
72\end{array}$} & \multirow{2}{*}{$\begin{array}{c}\begin{array}{c}\text { Date } \\
\text { Electrified }\end{array} \\
1920\end{array}$} & \multirow{2}{*}{$\begin{array}{c}\text { System } \\
\text { D.C. shunt } \\
\text { and series }\end{array}$} & \multirow{2}{*}{$\begin{array}{c}\text { Wet } \\
\text { End }\end{array}$} & \multicolumn{2}{|c|}{ Dry-end Motors } & \multirow{2}{*}{$\begin{array}{c}\text { Machine Speed Range } \\
\text { ft. per min. } \\
66 \cdot 6 \text { to } 200\end{array}$} & \multirow{2}{*}{$\begin{array}{c}\begin{array}{c}\text { Change Belts, } \\
\text { etc. }\end{array} \\
\text { No }\end{array}$} & \multirow{2}{*}{$\begin{array}{c}\text { Source of Supply } \\
\begin{array}{c}\text { Back-pressure } \\
\text { high-speed } \\
\text { engine }\end{array}\end{array}$} \\
\hline & & & & $\begin{array}{l}\text { h.p. } \\
25\end{array}$ & 400 to 1200 & & & \\
\hline 126 & $\begin{array}{l}1912 \\
(2) \\
1905 \\
(2)\end{array}$ & $\begin{array}{l}\text { D.C. shunt } \\
\text { and series } \\
\text { Ditto }\end{array}$ & - & 160 & $\begin{array}{l}250 \text { to } 660 \\
250 \text { to } 500\end{array}$ & 250 to 500 & No & $\begin{array}{l}\text { Back-pressure } \\
\text { high-speed } \\
\text { engine } \\
\text { Ditto }\end{array}$ \\
\hline $\begin{array}{r}80 \\
80 \\
130\end{array}$ & $\begin{array}{l}1900 \\
1900 \\
1900\end{array}$ & $\begin{array}{l}\text { D.C.potentio- } \\
\text { meter } \\
\text { Ditto } \\
\text { Ditto }\end{array}$ & - & 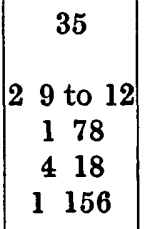 & $\begin{array}{l}730 \text { max. } \\
730 \text { max, } \\
730 \text { max. }\end{array}$ & $\begin{array}{l}0 \text { to } 200 \\
0 \text { to } 350 \\
0 \text { to } 350\end{array}$ & $\begin{array}{l}\text { No } \\
\text { No } \\
\text { No }\end{array}$ & $\begin{array}{l}\text { Condensing } \\
\text { engine } \\
\text { Ditto } \\
\text { Condensing } \\
\text { engine }\end{array}$ \\
\hline $\begin{array}{l}80 \\
70\end{array}$ & $\begin{array}{l}1901 \\
1913\end{array}$ & $\begin{array}{l}\text { D.C. shunt } \\
\text { and series } \\
\text { Ditto }\end{array}$ & - & $\begin{array}{l}40 \\
40\end{array}$ & $\begin{array}{l}210 \text { to } 840 \\
210 \text { to } 840\end{array}$ & $\begin{array}{l}40 \text { to } 160 \\
40 \text { to } 160\end{array}$ & $\begin{array}{l}\text { Yes } \\
\text { Yes }\end{array}$ & $\begin{array}{c}\text { Bleeding } \\
\text { turbine } \\
\text { Ditto }\end{array}$ \\
\hline 54 & 1919 & $\begin{array}{l}\text { D.C. shunt } \\
\text { and series }\end{array}$ & 10 & 30 & 350 to 700 & 100 to 200 & No & $\begin{array}{c}\text { Condensing } \\
\text { engine }\end{array}$ \\
\hline 72 & 1915 & $\begin{array}{c}\text { D.C.potentio- } \\
\text { meter } \\
\text { D.C.potentio- } \\
\text { meter and } \\
\text { shunt }\end{array}$ & Mec'l & 30 & $\begin{array}{l}1000 \text { max. } \\
1000 \text { on potentio- } \\
\text { meter } \\
1500 \text { on shunt }\end{array}$ & $\begin{array}{l}8 \text { to } 125 \\
11 \text { to } 96\end{array}$ & $\begin{array}{l}\text { One } \\
\text { One if } \\
\text { more } \\
\text { range } \\
\text { required }\end{array}$ & $\begin{array}{c}\text { Back-pressure } \\
\text { and low-speed } \\
\text { engine } \\
\text { Ditto }\end{array}$ \\
\hline $\begin{array}{l}66 \\
95\end{array}$ & $\begin{array}{l}1908 \\
1910 \\
1910\end{array}$ & $\begin{array}{l}\text { D.C. shunt } \\
\text { and series } \\
\text { Ditto } \\
\text { Ditto }\end{array}$ & - & $\begin{array}{l}45 \\
45 \\
45\end{array}$ & $\begin{array}{l}250 \text { to } 1000 \\
250 \text { to } 1000 \\
250 \text { to } 1000\end{array}$ & $\begin{array}{l}20 \text { to } 50 \text { to } 200 \\
20 \text { to } 50 \text { to } 200 \\
20 \text { to } 50 \text { to } 200\end{array}$ & $\begin{array}{l}\text { No } \\
\text { No } \\
\text { No }\end{array}$ & $\begin{array}{l}\text { Condensing } \\
\text { engine } \\
\text { Ditto } \\
\text { Ditto }\end{array}$ \\
\hline $\begin{array}{l}72 \\
74\end{array}$ & $\begin{array}{l}1915 \\
1919\end{array}$ & $\begin{array}{c}\text { D.C. shunt } \\
\text { and series } \\
\text { Ditto }\end{array}$ & 14 & 33 & $\begin{array}{l}450 \text { to } 1200 \\
450 \text { to } 1200\end{array}$ & $\begin{array}{l}17 \text { to } 180 \\
17 \text { to } 180\end{array}$ & $\begin{array}{l}\text { One } \\
\text { One }\end{array}$ & $\begin{array}{l}\text { Condensing } \\
\text { engine } \\
\text { Ditto }\end{array}$ \\
\hline 90 & 1905 & $\begin{array}{l}\text { D.C. shunt } \\
\text { and series }\end{array}$ & 24 & 65 & 560 to 1000 & 40 to 200 & One & $\begin{array}{c}\text { Back-pressure } \\
\text { high-speed } \\
\text { engine }\end{array}$ \\
\hline 96 & 1913 & $\begin{array}{l}\text { Multi-motor } \\
\text { potentio- } \\
\text { meter }\end{array}$ & - & $\begin{array}{r}20 \\
10 \\
40 \\
8 \\
24\end{array}$ & $\begin{array}{l}\text { Couch, wet press, } \\
\text { cylinders, } \\
\text { reel } \\
1170 \text { mean } \\
3 \text { to } 1 \text { range }\end{array}$ & 20 to $60^{\circ}$ & $\begin{array}{l}\text { Proved } \\
\text { unsatis- } \\
\text { factory, } \\
\text { since } \\
\text { discarded } \\
\text { Yes }\end{array}$ & $\begin{array}{l}\text { Separately- } \\
\text { excited } \\
\text { generator ; } \\
49 \mathrm{~kW} \\
\text { Condensing } \\
\text { engine }\end{array}$ \\
\hline
\end{tabular}


can be realized. The d.c. single-motor systems, of course, predominate in this table, as the a.c. motor has only recently been made feasible.

It is noteworthy that half the equipments now running obtain their power from a condensing prime mover, apparently using live steam for heating the dryers. This method obviously can be improved upon.

The author's opinion is that electrification of existing machines will generally be on the single-motor system, as unless the gear at the back of the machine is worn out the expense of the multi-motor system cannot be justified.

For new machines, however, the multi-motor system has the following good points:-
(1) The cost of machine and drive is little, if any, more costly, no gearing being required.

(2) With the extra-high-speed news machines now being developed, the gearing is getting almost beyond practical limits.

(3) By cutting out the gearing, a narrower machinehouse will suffice, thus making a marked saving in building and foundation costs.

(4) When considering the installation of a new machine to replace an existing one, the multi-motor system will enable a wider machine (with consequent increased production) to be placed in the same machine house, due to the reduced space required for the drive.

\section{Discussion before the North-Western Centre, at Manchester, 8 March, 1921.}

Mr. F. G. Anderson : I was somewhat disappointed with the paper in so far as it deals with the driving of paper machines. It seems to show that the author is not very dissatisfied with the old drives with their clutches, cone pulleys, etc. No doubt belt drives are fairly satisfactory for many classes of work and for moderate-speed machines, but they leave much to be desired when used for larger machines at high speeds. As the author says on page $\mathbf{5 5 0}$ under "Multi-motor Systems," an essential condition of any drive is a constant "draw" between sections. I maintain that we do not get it with the old drives, or at any rate only approximately. I should like to quote an American authority who deals with the subject of belt slip which is very pertinent to this matter. Professor Sawdon claims that the tests which were carried out at Sibley College, Cornell University, are probably the most thorough tests ever taken on belt slip and creep. They cover a period of 11 months, during which 9000 observations were taken on a machine especially constructed to measure slip and creep, etc. He says : "By taking continuous observations of slip over long intervals of time, with the machine running under constant conditions of tension, brake load and speed, data were collected and curves plotted between per cent of slip and time." The slip varied over a period of $\mathbf{3 0}$ minutes between 0.5 and 14 per cent on the top curve, and on the bottom curve between 1 and over 10 per cent. This authority says the curves are perfectly typical. "From these it will be seen that the slip is continually varying. By comparing a large number of such curves it was found that this variation takes place through no clearly defined cycle." Had the belt speed during test been high one might have suggested air pockets, but the conditions of test prevent any such thought; the belt speed over all tests was low, i.e. 2200 r.p.m. A particular test was made on a load increase of 20 per cent. The belt was supposed to be normally loaded after the increase, and the tension ratio was 3.57 per cent. The slip had changed from $2 \cdot 26$ to $3 \cdot 29$ per cent, i.e. more than 1 per cent. If this were applied to two sections of a paper machine between which the "draw" is set at 1 per cent or possibly $\frac{1}{2}$ per cent, a 20 per cent change of load takes place, caused by additional weights or increased friction; we find that the slip has changed on the section by 1 per cent, but as the "draw" was only 1 per cent this figure has doubled, or in the case of the "draw" set at $\frac{1}{2}$ per cent the change would be 200 per cent. Cone pulleys are extensively employed on paper machines. The velocity of the large diameter is not the same as that of the small diameter. With which velocity does the belt agree? Friction losses must be greater, whilst the points above referred to are common to any fiat-pulley drive and are clearly greatly aggravated in the case of a cone pulley. A paper maker stated some time ago that his machine was driven by a steam engine; subsequently, he changed it to a single-motor drive, retaining the drive otherwise as before, and as a result he calculated that he could quote $\mathbf{1 5}$ per cent less on a specification. The paper machine can now be a positive instrument in the hands of the operator, as with the Harland interlock constant "draw" can be maintained absolute. This should result in better paper or more production. The author mentions " hunting." There was a little hunting on the experimental machine, due to play in the bearings and slackness and wear in the pinion teeth. The play was such that it was extraordinary that satisfactory paper could be made under these conditions, and it is a point in favour of the regulator that it succeeded in maintaining a control sufficiently accurate to make paper; but under these conditions it is not surprising that it was difficult to make up for the play above referred to. There is no difficulty whatever in arranging a direct-current control which will be free from objectionable jumps when the speed of the machine is varied. The early efforts with individual motor-drives showed more courage and enthusiasm than knowledge, and I have little hesitation in saying that by applying a multi-motor drive without any control to a paper machine, the engineer was making the speed regulation worse than with a belt drive. Interlock control reflects any fluctuations, not in revolutions but in degrees of angular displacement, and it ensures that the drive will make the same number of revolutions per second, and the synchronism between the master and any one section is absolute. Sections can be started up one at a time and interlocked. The Harland interlock control is available for either direct-current or alternating-current drives. The Laurentide machine running 